\title{
Evaluation of the knowledge, attitudes and behaviors of pre-school teachers on oral and dental health in the city center of Trabzon
}

\section{Purpose}

Educators can also contribute to the prevention of early childhood caries (ECC) by educating children about oral diseases and hygiene practices. The aim of this study was to assess the knowledge, attitudes, and behaviors of pre-school teachers concerning oral and dental health in Trabzon.

\section{Subjects and methods}

The study was carried out with 226 pre-school teachers in the city center using a self-administered questionnaire to evaluate their knowledge, attitudes, and behaviors concerning the oral and dental health of children.

\section{Results}

Only $29.8 \%$ of the respondents had a prior dental education. Although $83 \%$ of the teachers said that regular visits to the dentist were effective for caries prevention, only $13.2 \%$ said that they made regular visits to a dentist. Approximately $65.8 \%$ of the teachers agreed that fluoride strengthens tooth enamel and $35.1 \%$ of the teachers said that there were oral health activities in their schools. Additionally, $74.6 \%$ of teachers said that they would participate in dental education about children's oral health in the future.

\section{Conclusion}

Preventive dental health program could be implemented including the proper behaviors related to the importance and treatability of primary teeth, first tooth cleaning, dental visits, the use of fluoride toothpaste, and oral hygiene into the preschool teachers' undergraduate education programs in the future. This program should be repeated at certain intervals for the prevention of ECC.

Keywords: Dental education; oral health; preschool; early childhood caries; teacher

\section{Introduction}

Starting in the prenatal period, it is important to raise parental awareness for early childhood caries (ECC), which includes clarifying incomplete or incorrect knowledge and reshaping the attitudes and behaviors of the parents; these are essential factors for the prevention of ECC. Therefore, the knowledge level of the occupational groups who are in contact with the affected age groups and their parents is important for guiding the parents by providing correct information. One of these occupational groups comprises of teachers. Teachers may be considered alternative staff members in the struggle against dental caries, a preventable disease because they are able to affect a large number of children and parents. The healthy behaviors and lifestyles that are formed in the early years of life are more permanent than those acquired later. The messages required for a healthy life can be repeated every school year (1).

\author{
Ezgi Baltacı ${ }^{1} \mathbb{D}$, \\ Özgül Baygın² (D, \\ Tamer Tüzüner ${ }^{2} \mathbb{B}$, \\ Fatih Mehmet Korkmaz ${ }^{3}$
}

Presented at: $24^{\text {th }}$ Congress of Turkish Society of Pediatric Dentistry, 19-22 October 2017, Antalya, Turkey

ORCIDIDs of the authors: E.B. 0000-0001-8553-3858; Ö.B. 0000-0003-0836-7619; T.T. 0000-0001-5817-5928; F.M.K. 0000-0001-9324-2014

'Trakya University, Faculty of Dentistry, Department of Pediatric Dentistry, Edirne, Turkey

${ }^{2}$ Karadeniz Technical University, Faculty of Dentistry, Department of Pediatric Dentistry, Trabzon, Turkey

${ }^{3}$ Karadeniz Technical University, Faculty of Dentistry, Department of Prosthodontics, Trabzon, Turkey

Corresponding Author: Özgül Baygın E-mail:dtozgul@gmail.com

Received: April 26, 2018 Revised: September 6, 2018 Accepted: December 12, 2018

DOI: 10.26650/eor.20199213 
Schools have an important role in developing programs for the prevention of oral and dental health problems during childhood. There are studies reporting children who are at school for an education are more likely to be positively affected (2). Children need to be given health education to create good oral and dental health, and this education is supposed to cause a beneficial behavioral change in the child. Behavioral changes occur through regular and longterm health education. For this reason, schools are suitable centers for health education because they provide a stable environment and stable conditions. Knowledgeable and communicable teachers are the basic element in the oral and dental health education provided at schools. It is important for the curricula at vocational high schools or the faculties of prospective teachers to incorporate health topics, including health improvement and prevention. Additionally, the content and duration of the curriculum are significant. Moreover, the health education should be made permanent in order to ensure that teachers receive up-to-date health information after graduation (3-6).

One of the important factors in oral health is the management of dental injuries. Since children are involved in sporting activities at school and in situations with close contact or physical activity, eventual injuries may occur due to falls, accidents, etc. Successful management of the process from the time of the incident to the time of the dental visit in these trauma cases increases the chance of successful posttraumatic treatments. Good management of this process depends on the knowledge level of the teacher. The proper orientation of a child and his/her parents can give the dentist a chance for early intervention. It is important for a teacher to know what to do in case of an emergency with regard to the primary and permanent teeth (3-9).

Many studies have shown that the use of teachers in improving the oral health of schoolchildren is successful (10). However, according to some reports, teachers are reluctant to take part in oral health programs requiring supervision (11). It is thought that this may be related to the lack of knowledge of teachers concerning oral health issues (12). The inadequate training of teachers on this subject can cause them to give incomplete or incorrect information to students or not teach the students effectively. In addition, a lack of necessary tools, resources, time, and integrated curriculum of oral health education are some of the limitations of school-based dental education (13).

It is crucial for pre-school and classroom teachers, who have been in contact with children for a long time and have an influence on their education, to receive oral and dental health education. Children spend most of their time in school, especially throughout their formative years. The role of a teacher is critical in these developmental processes. It is internationally recognized that teachers now play a potentially important role in school-based dental education, so the knowledge level of teachers on oral and dental health is very important (14).

The purpose of this study is to identify the knowledge level, attitudes and behaviors of pre-school teachers in the city center of Trabzon concerning oral and dental health, to determine areas of incomplete or incorrect knowledge by conducting a questionnaire, to raise awareness about oral and dental health in pre-school teachers and to ensure that pre-school teachers guide children and their parents with regard to the correct practices.

\section{Subjects and Methods}

\section{Study design}

The ethics committee approval for the study was received from the Karadeniz Technical University Faculty of Medicine Clinical Research Ethics Committee (2015/103, 04/11/2015), and the necessary permissions were received from Trabzon Governorship Provincial Directorate of National Education. According to the data obtained from the latter governing body, it was determined that there are 564 pre-school teachers in Trabzon, 306 of whom are in the city center. The names and addresses of the schools affiliated with the central district, including the nursery classes, were obtained from the Provincial Directorate of National Education.

In total, 72 schools and 226 teachers received a questionnaire. Teachers were visited at their schools, which were located in the city center of Trabzon, and they were given a questionnaire evaluating their knowledge, attitudes, and behaviors regarding the oral health of children and occupational health. The questionnaire included 40 questions and consisted of three parts. The first part had questions related to demographic information, the second part aimed to measure the level of general knowledge about oral health, and the third part included informational questions about the attitudes and behaviors of the teachers concerning oral health. The types of questions in the questionnaire were open-ended, closed-ended, and multiple choice.

After preparation of the questionnaire, a pilot study was conducted with 10 teachers; the existence of incomprehensible questions was identified, the opinions of the teachers were evaluated, and the necessary corrections were made. Then, the teachers were visited, the purpose of the study was briefly explained, and the questionnaire was given to the voluntary participants. It took an average of 10 minutes for the teachers to complete the questionnaire, and while the teacher was responding to the questionnaire (within working hours), the researcher waited at a certain distance and answered only the questions that the teacher could not understand. Those who were not available or at school on the day of the questionnaire or did not want to participate were excluded from the study. The demographic information section of the questionnaire asked about age, gender, marital status, parental status, number of children, monthly income, duration of professional experience, and whether they received any previous education concerning children's oral health.

The second part, which measured the knowledge of oral health, included information on the consequences of periodontal problems, factors causing decay, effective methods for caries prevention, information about primary teeth and general health, correct and incorrect known facts about fluoride, a child's first dental visit, teeth cleaning, appropriate nutritional options for children, and information on what can be done about permanent and primary teeth dentition trauma.

The third part, which investigated the attitudes and behaviors of teachers concerning their own oral health, included questions about the frequency, duration and time of tooth brushing, preferred tools for interface cleaning, frequency of dental visits, reasons for visiting the dentist, 
their views on the attitudes toward the preventive treatments of dentists and the availability of activities related to oral and dental health education in their schools.

\section{Statistical analysis}

SPSS sotware (IBM Corp. Released 2013. IBM SPSS Statistics for Windows, Version 22.0. Armonk, NY: IBM Corp, USA) was used for the statistical analysis. Descriptive statistics, the comparison of the average scores and related tests were performed. In the questions regarding preventive dentistry, a Chi-square test was used to examine the relationship between correct responses and the status of receiving training, the duration of professional experience, and parental status. Confidence interval was set to $95 \%$ and $p<0.05$ was considered statistically significant.

\section{Results}

The results show that, in the survey, 126 of 226 teachers were female, 100 were male, $69.3 \%$ had previous education on oral and dental health, $67.5 \%$ had children, and $27.2 \%$ had more than 10 years of professional experience. The evaluation of teachers' knowledge of tooth decay is given in Table 1. Among the teachers who think that it is possible to have noncarious teeth, there are no statistically significant difference $s$ between the ones who have had education on oral health and those who have not; the ones who have children and those who do not; and the ones whose professional experience was more than 10 years or was less than 10 years $(p>0.05)$. Among those who think that the problems in the primary teeth affect permanent teeth and those who think that caries in the primary teeth is treatable, no statistically significant difference was found in terms of previous oral health education, parental status or professional experience $(p>0.05)$ (Table 2). As the most effective method for preventing tooth decay, the items regarding tooth brushing (211 people, 92.5\%), visiting the dentist regularly (190 people, $83.3 \%$ ), using dental floss (161 people, 70\%), limiting sugary snacks (158 people, 69.3\%), using fluoride dental products (89 people, 39\%) and chewing sugarless gum (56 people, $24.6 \%$ ) were chosen. A significant difference exists between the teachers choosing the item "using fluoride dental products" in terms of being educated on oral and dental health or not $(p>0.05)$. Accordingly, it is understood that the educated people were of the opinion that consuming fluoride dental products prevented decay. An examination of the other chosen options demonstrated no significant difference in terms of being educated on oral and dental health, parental status or the duration of professional experience $(p>0.05)$ (Table 3$)$.

The number of people who think that dental hygiene in children should start at the time of first tooth eruption is 115 (50.4\%). Previous education concerning oral and dental health, parental status or the duration of professional experience did not cause any statistically significant result for the teachers who selected this option ( $p>0.05)$. Among the 40 teachers (17.5\%) who reported that the first dental visit should not occur until after a child is 1 year old, there is no statistically significant difference in terms of previous education concerning oral and dental health, parental status or the duration of professional experience ( $p>0.05)$ (Table 4).
In terms of previous oral and dental health education, parental status, or a professional experience more than 10 years $(p<0.05)$, statistically significant results were found among 150 (65.8\%) teachers who believe that fluoride strengthens tooth enamel. The number of teachers who stated that fluoride is nutritional for teeth and bones is 100 (36.8\%), and among them, a statistically significant difference was identified in terms of being educated on oral and dental health $(p<0.05)$, but not in terms of the duration of professional experience or parental status $(p>0.05)$. A total of 116 teachers (50.9\%) noted that fluoride is an anti-oral bacterial agent and, among them, there was a statistically significant difference in terms of being educated on oral and dental health education $(p<0.05)$, but no statistically significant difference was found in terms of parental status or the duration of professional experience ( $p>0.05)$. Among 69 teachers (30.3\%) who noted that the fluoride can treat initial caries, there was a statistically significant difference in terms of being educated on oral and dental health and having more than 10 years of professional experience $(p<0.05)$, but being a parent had no significant effect on this option ( $p>0.05)$. A total of 54 (23.7\%) teachers thought that the use of fluoride toothpaste should start in children who were approximately 3 years old, and there was not any statistically significant difference in terms of being educated on oral and dental health, parental status or the duration of professional experience ( $p>0.05$ ) (Table 5).

A total of $161(70.6 \%)$ the teachers indicated that evaluation should be done as soon as possible in the case of mouth injuries/traumas. Among those having oral and dental health education and having children, there was no significant difference $(p>0.05)$, but a statistically significant difference existed in the teachers with less than 10 years of professional experience $(p<0.05)$. The question, "Which one is best to do for the primary tooth that has been completely removed as a result of injury, falling, etc.?" was answered as "It should never be replaced" by 51 teachers (22.4\%) and "I do not know" by 107 teachers (46.9\%). No statistically significant difference was found in these respondents in terms of receiving oral and dental health education, parental status or the duration of professional experience ( $p>0.05)$. The question, "Which one is best to do for the permanent tooth which has completely removed as a result of injury, falling, etc.?" was answered with, "Find the tooth" by 32 teachers, (20.2\%), "Rinse it" by 46 teachers (20.2\%), "Replace it immediately" by 29 teachers (12.7\%), and "I do not know" by 151 teachers (66.2\%). Among the respondents who chose these options, there was not any statistically significant difference in terms of receiving oral and dental health education, parental status, or the duration of professional experience ( $p>0.05$ ) (Table 6).

An evaluation of the personal oral hygiene behaviors of the teachers showed that $73.2 \%$ of the teachers brushed their teeth twice a day, but tooth-brushing time was less than 2 minutes; $51.3 \%$ of the teachers changed their toothbrushes every 3 months, and only $46.1 \%$ used dental floss. Although regular dental visits were one of the most frequently chosen options for the prevention of tooth decay, only $13.2 \%$ of the teachers went to the dentist at regular intervals, $42.1 \%$ of the teachers visited the dentist only when they had a toothache, $58.8 \%$ of the teachers had the most recent visit to the dentist for tooth decay/fillings, and 33.3\% of the teachers did not pay enough attention to the preventive treatments by dentists. 
Table 1. Evaluation of the knowledge of teachers about tooth decay.

\begin{tabular}{lcc} 
& Number & Percentage \\
\hline What are the causes of tooth decay? & & $\% 91,2$ \\
\hline Inadequate brushing. & 208 & $\% 82,9$ \\
\hline Sweet and acidic foods. & 189 & $\% 64,5$ \\
\hline Lack of regular dental check. & 147 & $\% 39,8$ \\
\hline Dental plaque. & 91 & $\% 94,7$ \\
\hline Oral and dental health affects general health. & 216 & $\% 75$ \\
\hline It is possible to have non-carious teeth. & 171 & $\% 61,8$ \\
\hline Problems in primary teeth affect permanent teeth. & 141 & $\% 69,3$ \\
\hline Caries in primary teeth are treatable. & 158 & \\
\hline
\end{tabular}

Table 2. The relationship between the knowledge of dental caries and education, parental status, and professional experience.

$\begin{array}{ccccccccc}\begin{array}{c}\text { Those } \\ \text { who have } \\ \text { received } \\ \text { education }\end{array} & \begin{array}{c}\text { Those who } \\ \text { have not } \\ \text { received } \\ \text { education }\end{array} & \begin{array}{c}p \\ \text { value }\end{array} & \begin{array}{c}\text { Those with } \\ \text { children }\end{array} & \begin{array}{c}\text { Those } \\ \text { without } \\ \text { children }\end{array} & \begin{array}{c}p \\ \text { value }\end{array} & \begin{array}{c}<10 \text { years } \\ \text { professional } \\ \text { experience }\end{array} & \begin{array}{c}\text { professional } \\ \text { experience }\end{array} & \begin{array}{c}p \\ \text { value }\end{array} \\ & & & & \end{array}$

\begin{tabular}{|c|c|c|c|c|c|c|c|c|c|}
\hline $\begin{array}{l}\text { It is possible } \\
\text { to have } \\
\text { non-carious } \\
\text { teeth }\end{array}$ & $\begin{array}{l}n=55 \\
\% 77,9\end{array}$ & $\begin{array}{l}n=116 \\
\% 73,4\end{array}$ & 0,582 & $\begin{array}{l}n=111 \\
\% 72,1\end{array}$ & $\begin{array}{l}n=60 \\
\% 81,1\end{array}$ & 0,191 & $\begin{array}{l}n=125 \\
\% 42,8\end{array}$ & $\begin{array}{l}n=46 \\
\% 64,5\end{array}$ & 1,000 \\
\hline $\begin{array}{l}\text { Problems } \\
\text { in primary } \\
\text { teeth affect } \\
\text { permanent } \\
\text { teeth }\end{array}$ & $\begin{array}{l}n=43 \\
\% 70,5\end{array}$ & $\begin{array}{l}n=98 \\
\% 71\end{array}$ & 1,000 & $\begin{array}{l}n=94 \\
\% 67,1\end{array}$ & $\begin{array}{l}n=47 \\
\% 77\end{array}$ & 0,214 & $\begin{array}{l}n=104 \\
\% 70,7\end{array}$ & $\begin{array}{l}n=37 \\
\% 31\end{array}$ & 0,895 \\
\hline $\begin{array}{l}\text { Caries in } \\
\text { primary } \\
\text { teeth are } \\
\text { treatable. }\end{array}$ & $\mathrm{n}=54$ & $\begin{array}{c}n=102 \\
\% 75\end{array}$ & 0,190 & $\mathrm{n}=105$ & $\mathrm{n}=53$ & 0,545 & $\begin{array}{l}n=105 \\
\% 74,5\end{array}$ & $\begin{array}{l}n=53 \\
\% 86,9\end{array}$ & 0,076 \\
\hline
\end{tabular}

Table 3. The relationship between the knowledge of the prevention of decay and parental status and professional experience $\left(^{*} p<0.05\right.$ was considered statistically significant).

\begin{tabular}{|c|c|c|c|c|c|c|c|c|c|}
\hline $\begin{array}{l}\text { Which } \\
\text { method } \\
\text { is more } \\
\text { effective } \\
\text { for you to } \\
\text { prevent } \\
\text { tooth decay? }\end{array}$ & $\begin{array}{l}\text { Those } \\
\text { who have } \\
\text { received } \\
\text { education }\end{array}$ & $\begin{array}{l}\text { Those who } \\
\text { have not } \\
\text { received } \\
\text { education }\end{array}$ & $\begin{array}{c}p \\
\text { value }\end{array}$ & $\begin{array}{c}\text { Those with } \\
\text { children }\end{array}$ & $\begin{array}{l}\text { Those } \\
\text { without } \\
\text { children }\end{array}$ & $\begin{array}{c}p \\
\text { value }\end{array}$ & $\begin{array}{c}<10 \text { years } \\
\text { professional } \\
\text { experience }\end{array}$ & $\begin{array}{c}>10 \text { years } \\
\text { professional } \\
\text { experience }\end{array}$ & $\begin{array}{c}p \\
\text { value }\end{array}$ \\
\hline $\begin{array}{l}\text { Limiting } \\
\text { sugary } \\
\text { snacks. }\end{array}$ & $\begin{array}{c}n=53 \\
\% 77,9\end{array}$ & $\begin{array}{l}n=103 \\
\% 65,2\end{array}$ & 0,081 & $\begin{array}{l}n=105 \\
\% 68,2\end{array}$ & $\begin{array}{l}n=53 \\
\% 71,6\end{array}$ & 0,708 & $\begin{array}{l}n=113 \\
\% 68,1\end{array}$ & $\begin{array}{c}n=45 \\
\% 72,6\end{array}$ & 0,620 \\
\hline $\begin{array}{l}\text { Using } \\
\text { fluoride } \\
\text { dental } \\
\text { products. }\end{array}$ & $\begin{array}{c}n=40 \\
\% 58\end{array}$ & $\begin{array}{c}n=47 \\
\% 29,7\end{array}$ & $0,000^{*}$ & $\begin{array}{l}n=55 \\
\% 35,7\end{array}$ & $\begin{array}{l}n=34 \\
\% 45,9\end{array}$ & 0,138 & $\begin{array}{l}n=63 \\
\% 38\end{array}$ & $\begin{array}{c}n=26 \\
\% 41,9\end{array}$ & 0,583 \\
\hline $\begin{array}{l}\text { Chewing } \\
\text { sugarless } \\
\text { gum. }\end{array}$ & $\begin{array}{c}n=20 \\
\% 29,4\end{array}$ & $\begin{array}{l}n=36 \\
\% 22,8\end{array}$ & 0,373 & $\begin{array}{l}n=36 \\
\% 23,4\end{array}$ & $\begin{array}{c}n=20 \\
\% 27\end{array}$ & 0,663 & $\begin{array}{l}n=39 \\
\% 23,5\end{array}$ & $\begin{array}{l}n=17 \\
\% 27,4\end{array}$ & 0,660 \\
\hline $\begin{array}{l}\text { Brushing } \\
\text { teeth. }\end{array}$ & $\begin{array}{c}n=60 \\
\% 88,2\end{array}$ & $\begin{array}{l}n=149 \\
\% 94,3\end{array}$ & 0,190 & $\begin{array}{l}n=139 \\
\% 90,3\end{array}$ & $\begin{array}{c}n=72 \\
\% 97,3\end{array}$ & 0,104 & $\begin{array}{l}n=154 \\
\% 92,8\end{array}$ & $\begin{array}{c}n=57 \\
\% 91,9\end{array}$ & 0,783 \\
\hline $\begin{array}{l}\text { Using dental } \\
\text { floss. }\end{array}$ & $\begin{array}{c}n=44 \\
\% 64,7\end{array}$ & $\begin{array}{l}n=115 \\
\% 72,8\end{array}$ & 0,289 & $\begin{array}{l}n=104 \\
\% 67,5\end{array}$ & $\begin{array}{l}n=57 \\
\% 77\end{array}$ & 0.187 & $\begin{array}{l}n=114 \\
\% 68,7\end{array}$ & $\begin{array}{c}n=47 \\
\% 75,8\end{array}$ & 0,374 \\
\hline $\begin{array}{l}\text { Regular } \\
\text { dental visits. }\end{array}$ & $\begin{array}{c}n=51 \\
\% 75\end{array}$ & $\begin{array}{l}n=137 \\
\% 86,7\end{array}$ & 0,049 & $\begin{array}{c}n=126 \\
\% 81,8\end{array}$ & $\begin{array}{c}n=64 \\
\% 86,5\end{array}$ & 0,487 & $\begin{array}{l}n=138 \\
\% 83,1\end{array}$ & $\begin{array}{c}n=52 \\
\% 83,9\end{array}$ & 1,000 \\
\hline
\end{tabular}


Table 4. The relationship between the knowledge of the first dental hygiene and dental visits of children and education, parental status and professional experience.

\begin{tabular}{|c|c|c|c|c|c|c|c|}
\hline $\begin{array}{l}\text { Those } \\
\text { who have } \\
\text { received } \\
\text { education }\end{array}$ & $\begin{array}{l}\text { Those who } \\
\text { have not } \\
\text { received } \\
\text { education }\end{array}$ & $\begin{array}{l}\mathbf{p} \\
\text { value }\end{array}$ & $\begin{array}{l}\text { Those with } \\
\text { children }\end{array}$ & $\begin{array}{l}\text { Those } \\
\text { without } \\
\text { children }\end{array}$ & $\begin{array}{l}\mathbf{p} \\
\text { value }\end{array}$ & $\begin{array}{l}<10 \text { years } \\
\text { professional } \\
\text { experience }\end{array}$ & $\begin{array}{l}>10 \text { years } \\
\text { professional } \\
\text { experience }\end{array}$ \\
\hline
\end{tabular}

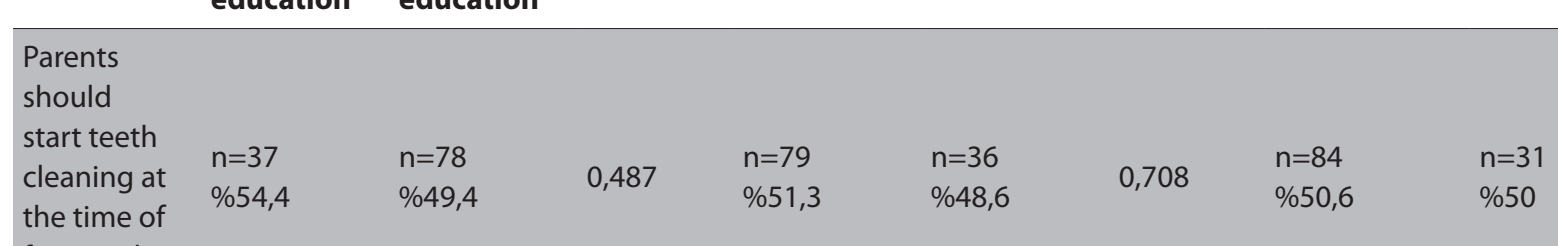

first tooth

eruption.

The first

dental visits

of children

should not

$\mathrm{n}=13$

$\mathrm{n}=27$

$\% 19,1$

$\% 17,1$

0,860

$\mathrm{n}=22 \quad \mathrm{n}=18$

$\% 14,3$

$\% 24,3$

0,093

$\mathrm{n}=28$

$\mathrm{n}=12$

be later than

1 year old.

Table 5. The relationship between the knowledge of fluoride and education, parental status and professional experience $\left({ }^{*} p<0.05\right.$ was considered statistically significant).

\begin{tabular}{|c|c|c|c|c|c|c|c|c|}
\hline $\begin{array}{c}\text { Those } \\
\text { who have } \\
\text { received }\end{array}$ & $\begin{array}{c}\text { Those who } \\
\text { have not } \\
\text { education }\end{array}$ & $\begin{array}{c}p \\
\text { value }\end{array}$ & $\begin{array}{c}\text { Those with } \\
\text { children }\end{array}$ & $\begin{array}{c}\text { Those } \\
\text { without } \\
\text { children }\end{array}$ & $\begin{array}{c}p \\
\text { value }\end{array}$ & $\begin{array}{c}<10 \text { years } \\
\text { professional } \\
\text { experience }\end{array}$ & $\begin{array}{c}>10 \text { years } \\
\text { professional } \\
\text { experience }\end{array}$ & $\begin{array}{c}p \\
\text { value }\end{array}$ \\
\hline
\end{tabular}

\begin{tabular}{|c|c|c|c|c|c|c|c|c|c|}
\hline $\begin{array}{l}\text { Fluoride } \\
\text { strengthens } \\
\text { the tooth } \\
\text { mine. }\end{array}$ & $\begin{array}{c}n=61 \\
\% 89,7\end{array}$ & $\begin{array}{l}n=87 \\
\% 55,1\end{array}$ & $0,000 *$ & $\begin{array}{c}n=94 \\
\% 61\end{array}$ & $\begin{array}{c}n=56 \\
\% 75\end{array}$ & $0,042 *$ & $\begin{array}{l}n=102 \\
\% 61,4\end{array}$ & $\begin{array}{c}n=48 \\
\% 77,4\end{array}$ & $0,035^{*}$ \\
\hline $\begin{array}{l}\text { Fluoride is } \\
\text { nutritional } \\
\text { for teeth } \\
\text { and bones. }\end{array}$ & $\begin{array}{c}n=35 \\
\% 51,5\end{array}$ & $\begin{array}{c}n=47 \\
\% 29,7\end{array}$ & $0,002^{*}$ & $\begin{array}{c}n=56 \\
\% 36,4\end{array}$ & $\begin{array}{c}n=28 \\
\% 37,8\end{array}$ & 0,829 & $\begin{array}{c}n=61 \\
\% 36,7\end{array}$ & $\begin{array}{c}n=23 \\
\% 37,1\end{array}$ & 1,000 \\
\hline $\begin{array}{l}\text { Fluoride is } \\
\text { an anti-oral } \\
\text { bacterial } \\
\text { agent. }\end{array}$ & $\begin{array}{c}n=45 \\
\% 66,2\end{array}$ & $\begin{array}{c}n=69 \\
\% 56,3\end{array}$ & $0,003^{*}$ & $\begin{array}{c}n=77 \\
\% 50\end{array}$ & $\begin{array}{l}n=39 \\
\% 52,7\end{array}$ & 0,702 & $\begin{array}{c}n=81 \\
\% 48,8\end{array}$ & $\begin{array}{c}n=35 \\
\% 56,5\end{array}$ & 0,303 \\
\hline $\begin{array}{l}\text { Fluoride can } \\
\text { treat initial } \\
\text { caries. }\end{array}$ & $\begin{array}{c}n=34 \\
\% 50\end{array}$ & $\begin{array}{c}n=33 \\
\% 20,9\end{array}$ & $0,000^{*}$ & $\begin{array}{c}n=48 \\
\% 31,2\end{array}$ & $\begin{array}{c}n=21 \\
\% 28,4\end{array}$ & 0,783 & $\begin{array}{c}n=43 \\
\% 25,9\end{array}$ & $\begin{array}{c}n=26 \\
\% 41,9\end{array}$ & $0,019 *$ \\
\hline $\begin{array}{l}\text { Fluoride } \\
\text { toothpaste } \\
\text { in children } \\
\text { should start } \\
\text { around } 3 \\
\text { years old. }\end{array}$ & $\begin{array}{c}n=11 \\
\% 16,2\end{array}$ & $\begin{array}{c}n=43 \\
\% 27,2\end{array}$ & 0,106 & $\begin{array}{c}n=41 \\
\% 26,6\end{array}$ & $\begin{array}{c}n=13 \\
\% 17,6\end{array}$ & 0,180 & $\begin{array}{c}n=42 \\
\% 25,3\end{array}$ & $\begin{array}{c}n=12 \\
\% 19,4\end{array}$ & 0,444 \\
\hline
\end{tabular}

An evaluation of the teachers' attitudes toward oral and dental health showed that $64.9 \%$ of them did not have any activities concerning oral and dental health in their school, $55.7 \%$ knew that they had oral and dental health education in their school curriculum, $71.5 \%$ did not have any course on oral health care during their undergraduate education, and $74.6 \%$ of them would participate in a course on oral and dental health care in the future.

\section{Discussion}

Among childhood diseases, early childhood caries (ECC) continues to be a highly prevalent disease. ECC afflicts children's quality of life and their learning abilities (15-17). At the same time, other factors that should not be undervalued, including the fact that parents' quality of life is also affected (17), the financial burden that is encountered in coping 
Table 6. The relationship between the knowledge of oral injuries and education, parental status and professional experience $\left({ }^{*} p<0.05\right.$ was considered statistically significant).

\begin{tabular}{|c|c|c|c|c|c|c|c|c|c|}
\hline $\begin{array}{l}\text { Oral injuries/ } \\
\text { trauma }\end{array}$ & $\begin{array}{c}\text { Those } \\
\text { who have } \\
\text { received } \\
\text { education }\end{array}$ & $\begin{array}{l}\text { Those who } \\
\text { have not } \\
\text { education }\end{array}$ & $\begin{array}{c}p \\
\text { value }\end{array}$ & $\begin{array}{l}\text { Those with } \\
\text { children }\end{array}$ & $\begin{array}{c}\text { Those } \\
\text { without } \\
\text { children }\end{array}$ & $\begin{array}{c}p \\
\text { value }\end{array}$ & $\begin{array}{c}<10 \text { years } \\
\text { professional } \\
\text { experience }\end{array}$ & $\begin{array}{c}>10 \text { years } \\
\text { professional } \\
\text { experience }\end{array}$ & $\begin{array}{c}p \\
\text { value }\end{array}$ \\
\hline $\begin{array}{l}\text { Evaluation } \\
\text { should be } \\
\text { done as soon } \\
\text { as possible in } \\
\text { case of oral } \\
\text { injuries. }\end{array}$ & $\begin{array}{c}n=43 \\
\% 63,2\end{array}$ & $\begin{array}{l}n=116 \\
\% 73,4\end{array}$ & 0,124 & $\begin{array}{l}n=109 \\
\% 70,8\end{array}$ & $\begin{array}{l}n=52 \\
\% 70,3\end{array}$ & 1,000 & $\begin{array}{l}n=126 \\
\% 75,9\end{array}$ & $\begin{array}{l}n=35 \\
\% 56,5\end{array}$ & $0,004^{*}$ \\
\hline $\begin{array}{l}\text { A primary } \\
\text { tooth which } \\
\text { has removed } \\
\text { should never } \\
\text { be replaced. }\end{array}$ & $\begin{array}{l}n=19 \\
\% 27,9\end{array}$ & $\begin{array}{c}n=32 \\
\% 20,3\end{array}$ & 0,274 & $\begin{array}{c}n=31 \\
\% 20,1\end{array}$ & $\begin{array}{c}n=20 \\
\% 27\end{array}$ & 0,317 & $\begin{array}{c}n=41 \\
\% 24,7\end{array}$ & $\begin{array}{l}n=10 \\
\% 16,1\end{array}$ & 0,229 \\
\hline $\begin{array}{l}\text { Which one } \\
\text { is best to } \\
\text { do for the } \\
\text { permanent } \\
\text { tooth, } \\
\text { which has } \\
\text { completely } \\
\text { removed due } \\
\text { to an injury? }\end{array}$ & & & & & & & & & \\
\hline $\begin{array}{l}\text { Find the } \\
\text { tooth. }\end{array}$ & $\begin{array}{l}n=10 \\
\% 14,7\end{array}$ & $\begin{array}{c}n=22 \\
\% 13,9\end{array}$ & 1,000 & $\begin{array}{l}n=15 \\
\% 9,7\end{array}$ & $\begin{array}{c}n=17 \\
\% 23\end{array}$ & 0,013 & $\begin{array}{c}n=22 \\
\% 13,3\end{array}$ & $\begin{array}{c}n=10 \\
16,1\end{array}$ & 0,732 \\
\hline $\begin{array}{l}\text { Rinse the } \\
\text { tooth. }\end{array}$ & $\begin{array}{l}n=18 \\
\% 26,5\end{array}$ & $\begin{array}{l}n=28 \\
\% 17,7\end{array}$ & 0,187 & $\begin{array}{l}n=29 \\
\% 18,8\end{array}$ & $\begin{array}{c}n=17 \\
\% 23\end{array}$ & 0,580 & $\begin{array}{c}n=31 \\
\% 18,7\end{array}$ & $\begin{array}{l}n=15 \\
\% 24,2\end{array}$ & 0,460 \\
\hline $\begin{array}{l}\text { Replace } \\
\text { the tooth } \\
\text { immediately. }\end{array}$ & $\begin{array}{l}n=12 \\
\% 17,6\end{array}$ & $\begin{array}{l}n=17 \\
\% 10,8\end{array}$ & 0,229 & $\begin{array}{c}n=16 \\
\% 10,4\end{array}$ & $\begin{array}{c}n=13 \\
\% 17,6\end{array}$ & 0,190 & $\begin{array}{c}n=17 \\
\% 10,2\end{array}$ & $\begin{array}{c}n=12 \\
\% 19,2\end{array}$ & 0,106 \\
\hline I do not know & $\begin{array}{c}n=42 \\
\% 61,8\end{array}$ & $\begin{array}{l}n=107 \\
\% 67,7\end{array}$ & 0,386 & $\begin{array}{l}n=107 \\
\% 69,5\end{array}$ & $\begin{array}{c}n=44 \\
\% 59,5\end{array}$ & 0,134 & $\begin{array}{c}n=112 \\
\% 67,5\end{array}$ & $\begin{array}{l}n=39 \\
\% 62,9\end{array}$ & 0,623 \\
\hline
\end{tabular}

with ECC (16), and the life-long consequences of the risk of caries in primary dentition that could influence permanent dentition (18).

ECC is a preventable disease. It is a problem that arises due to social, behavioral, medical, and political reasons, and socioeconomic factors, family structure, and social dynamics need to be understood for its solution. ECC is often seen among disadvantaged individuals in the community. For a solution, health politics, social goals, and values need to be reviewed. ECC depends on behavioral elements because it is a result of the daily routines of the individuals around a child, such as parents, caregivers, grandparents. It is possible to create appropriate oral hygiene behaviors and to inform individuals about oral health and the effects of oral health on general health through community-based practices and education $(1,4,15)$.

Since there is no scientific evidence of the superiority of one method over another, the prevention of early childhood caries should not be based on a single approach (19). Therefore, the prevention of ECC requires disseminating information about ECC through approaches that concern the whole society and address its existing etiological reasons. The real challenge in the fight against ECC is to be able to attract the attention of mothers and children before problems arise. Information about ECC should be provided through the media, community education programs, courses for pre- and post-natal parents, women's health clinics, and schools. Education and motivation are not enough to make long-term changes. The behavior of individuals is usually shaped in early childhood and is rooted in the environment surrounding the child and the individual (20-22). To form a behavioral change in a child, it is necessary for the child to be informed by different sources of information and socially supported by his/her parents, peers, and other individuals in their daily lives (23). Teachers, as the people who spend the most time with children throughout their formative years after their parents, may play an important role in informing children about oral health and developing appropriate hygiene behaviors.

Within the scope of this cross-sectional study, primary and secondary schools in the center of Trabzon, including nursery classes, were visited, and 226 teachers were given a questionnaire on their knowledge, attitudes, and behaviors concerning oral and dental health. Our aim was to set the 
groundwork for the work that is needed to make school-based dental education a social practice by identifying the issues that teachers had incomplete or incorrect knowledge of. In addition, the teachers' correct answers were investigated in terms of receiving a previous education, parental status and the duration of their professional experience.

In total, $95.6 \%$ of the teachers in the study were female, and $94.7 \%$ of the teachers thought that oral and dental health affected general health. The proportion of teachers who had this opinion was $84.8 \%$ (26) and $74 \%(24)$ in the studies in Indian cities. In our study, $75 \%$ of teachers stated that it was possible to have non-carious teeth, $61.8 \%$ thought that the problems in the primary teeth affected permanent teeth, and $69.3 \%$ thought that tooth decay in a primary tooth was treatable. In a Nigerian study28, $89.4 \%$ of the teachers reported that tooth decay was not normal, $75 \%$ took dental problems seriously, and $76.9 \%$ responded that tooth loss can be avoided if it is treated.

Those who believed that using fluoride dental products was effective in preventing tooth decay was 39\% in our study, while the proportion was 6.2\% (26), 89\% (28) and 84\% (25) in other studies. The proportion of the teachers who thought that consuming fluoride tooth products were effective in preventing tooth decay was found to be significant in those who had received previous education concerning oral and dental health $(p<0.05)$. Compared with the other studies, the knowledge level of the teachers about fluoride tooth products seemed to be inadequate.

The American Academy of Pediatric Dentistry indicates that the cleaning of teeth should start when the first primary tooth is seen in the mouth and that parents must brush their children's teeth twice a day with a toothbrush that is suitable for the child's age. For children under 3 years old, 'a thin smear' or a 'rice size' portion of fluoride toothpaste should be used and, for those between 3-6 years, a 'pea size' portion of fluoride toothpaste should be used. In addition, within 6 months after the first tooth erupts, but before the baby is 1 year old, a dental visit is recommended for a caries risk assessment, parental education concerning oral hygiene and preventive methods, and guidance in oral diseases (29).

In our study, $50.4 \%$ of the teachers believed that children should start dental hygiene when their first tooth erupts, whereas $17.5 \%$ said that the first dentist visit should not be later than 1 year of age. It is determined that the teachers had incomplete knowledge about the guidance that can be effective in preventing early childhood decay. In similar studies with parents, $28.8 \%$ (30) and $52.5 \%$ (31) of the parents thought that the first dentist visits should be earlier than 1 year. We believe that the timing of the first dental visit and initial dental cleaning should be emphasized in the social awareness practices that are conducted for the prevention of ECC.

In our investigation of the knowledge level of fluoride, $65.8 \%$ of the teachers reported that fluoride toothpaste strengthens tooth enamel, and $30.3 \%$ indicated that fluoride toothpaste can treat initial tooth caries. Both outcomes are statistically significant in the teachers who received prior education and had more than 10 years of professional experience. In a similar study (14), $86.3 \%$, and $13.3 \%$ of the teachers thought that fluoride toothpaste strengthens tooth enamel and that it could treat initial caries, respectively. Accordingly, we believe that more comprehensive information on fluoride would be beneficial for raising social awareness and reducing the rising prejudice against fluoride.

For the trauma issue, our study showed that $70.6 \%$ of the teachers believed that interventions should be performed as soon as possible after the trauma. This rate was reported as $74.7 \%$ in another study (32). Unfortunately, in the case of avulsion-type injuries in primary and permanent teeth, the proportion of the teachers who believed that the tooth should be replaced immediately in permanent teeth avulsion was $12.7 \%$. This rate was $43 \%$ in a similar study in Singapore (33) and $16.2 \%$ in Hong Kong (32). Early interventions in traumatized teeth are described as extremely important for the long-term success of treatment in trauma cases $(34,35)$. In our study, $22.4 \%$ of the teachers thought that the primary tooth should never be replaced after primary dental avulsion. This rate was found to be $74.6 \%$ in teachers in Hong Kong (32). The fact that the teachers had inadequate knowledge complies with the current literature (36-38). The lack of information on trauma may be due to the lack of trauma experience of the teachers. Teachers' guidance is important for the prevention of trauma and for the proper orientation of parents after trauma. We suggest that the lack of information on this issue should be emphasized.

The curricula in our country's Pre-school and Classroom Teaching departments were reviewed in terms of their oral and dental health education. This examination revealed that there is a compulsory course in the pre-school program called "Mother-Child Health and Diseases" that is taught for 3 hours a week in the $3^{\text {rd }}$ semester. A topic regarding the oral and dental health of children is available in this course. Moreover, in the elective course, "Mother and Child Nutrition," the relationship between nutrition and oral and dental health is mentioned. Only $28.5 \%$ of the teachers reported that they had a lesson on oral health during their undergraduate studies. The proportion of the teachers whose schools had oral and dental health activities was $35.1 \%$, and $55.7 \%$ of the teachers noted that oral and dental health education for children existed in their school curriculum. In our study, $74.6 \%$ said that they would join an educational program about oral and dental health in children if it were given in the future. According to this result, we believe that the curriculum of pre-school teachers' faculties should have more oral hygiene topics. The underlying reasons why an oral health education was not be provided in some schools, even though the school curriculum included it, should be investigated and a solution can be provided. Dental education should be systematized and applied within the scope of health policies.

\section{Conclusion}

School-based dental education is one of the major social steps in fighting tooth decay. While teachers have knowledge of the causes of tooth decay and methods for preventing tooth decay in general, they do not have knowledge of protective practices, fluoride, first dental visits in children, first tooth cleaning and trauma, according to the results from our study. These deficiencies need to be addressed so that teachers can take an active role in school-based dental education, help parents, and positively influence children to help create healthy generations. If teachers have knowledge 
about the issue, they can educate children and parents more effectively. For the teachers to reach the desired level of knowledge, the importance of oral and dental health and their education should be emphasized, starting in the undergraduate programs, and continuing awareness about this issue should be made permanent.

Ethics committee approval: The ethics committee approval for the study was received from the Karadeniz Technical University Faculty of Medicine Clinical Research Ethics Committee (2015/103, 04/11/2015), and the necessary permissions were received from Trabzon Governorship Provincial Directorate of National Education.

Informed consent: Informed consent was provided by the participants' parents.

Author contributions: $E B$ and ÖB participated in designing the study. EB participated in generating the data for the study. EB and ÖB participated in gathering the data for the study. TT participated in the analysis of the data. TT and FMK wrote the majority of original draft of the paper. ÖB, TT and FMK participated in writing the paper. All authors approved the final version of the paper.

Conflict of interest: The authors have no conflicts of interest to declare.

Financial disclosure: The authors declared that this study has received no financial support.

Türkçe öz: Trabzon merkezindekiokullarda, okulöncesiöğretmenlerinin ağız ve diş sağlığı hakkındaki bilgi düzeylerinin değerlendirilmesi. Amaç: Okul öncesi eğitimciler; ağız ve diş sağlığı hakkında yeterli bilgi ve davranışlara sahip olurlarsa, okul temelli dental eğitimde rol alarak, aynı anda çok sayıda çocuk ve ebeveyne ulaşabilirler ve onları, ağız hastalıkları ve hijyen alışkanlıkları konusunda eğiterek erken çocukluk çağı çürüklerinin (EÇÇ) engellenmesine katkı sağlayabilirler. Bu çalışmanın amacı Trabzon merkezindeki okul öncesi öğretmenlerinin ağız ve diş sağlığı hakkındaki bilgi düzeylerini değerlendirerek eksik veya yanlış bilinen konuları saptamaktır. Bireyler ve yöntem: Çalışmada Trabzon merkezine bağlı ana sınıfı ve anaokullarına gidilerek toplamda 226 okul öncesi öğretmenine çocukların ağız ve iş sağlığı hakkında bilgi, tutum ve davranışlarını değerlendiren anket uygulaması yapıldı. Bulgular: Öğretmenlerin sadece \%29,8'inin daha öce ağız ve diş sağlığı ile ilgili eğitim aldığı tespit edildi. Çalıştıkları okullarda ağız ve diş sağlığı ile ilgili çalışmalar olan öğretmenlerin oranı \%35,1 olarak belirlendi. Öğretmenlerin \%74,6'sı ileride çocuklarda ağız ve diş sağlığı ile ilgili eğitim verildiğinde katılmak isteyeceğini belirtti. Koruyucu uygulamalar, ağız yaralanmaları ve ağı hijyeni alışkanlıkları konusunda bilgi eksiklikleri tespit edildi. Sonuç: Süt dişlerinin önemi, tedavi edilebilirliği, çocuklarda ilk diş temizliği ve diş hekimi ziyaretleri, çocuklarda fluorlu diş macunu kullanımı konusunda, ağız hijyeni ile doğru davranışlar ile ilgili uygun bir dental eğitim programı hazırlanarak okul öncesi öğretmenlerine lisans düzeyinden başlayarak belirli aralıklarla tekrarlanmasının EÇÇ'nin engellenmesi konusunda faydalı olacağı kanısındayız. Anahtar kelimeler: Ağız sağlığı; okul öncesi; bilgi; erken çocukluk çağı çürükleri; öğretmen

\section{References}

1. Petersen PE, Kwan S. Evaluation of community-based oral health promotion and oral disease prevention--WHO recommendations for improved evidence in public health practice. Community Dent Health 2004;21:319-9.

2. al-Tamimi S, Petersen PE. Oral health situation of schoolchildren, mothers and schoolteachers in Saudi Arabia. Int Dent J 1998;48:180-6. [CrossRef]

3. Kwan SY, Petersen PE, Pine CM, Borutta A. Health-promoting schools: an opportunity for oral health promotion. Bull World Health Organ 2005;83:677-5.
4. Tomar SL, Reeves AF. Changes in the oral health of US children and adolescents and dental public health infrastructure since the release of the Healthy People 2010 Objectives. Acad Pediatr 2009;9:388-95. [CrossRef]

5. Tinanoff N, Kanellis MJ, Vargas CM. Current understanding of the epidemiology mechanisms, and prevention of dental caries in preschool children. Pediatr Dent 2002;24:543-51.

6. Gussy MG, Waters EG, Walsh O, Kilpatrick NM. Early childhood caries:current evidence for etiology and prevention. J Paediatr Child Health 2006;42:37-43. [CrossRef]

7. Hallas D, Fernandez JB, Herman NG, Moursi A. Identification of Pediatric Oral Health Core Competencies through Interprofessional Education and Practice. Nurs Res Pract 2015; 2015:360523. doi:10.1155/2015/360523. [CrossRef]

8. Rowan-Legg A, Canadian Paediatric Society CPC. Oral health care for children - a call for action. Paediatr Child Health 2013;18:37-50. [CrossRef]

9. Flanders RA. Effectiveness of dental health educational programs in schools. J Am Dent Assoc 1987;114:239-42. [CrossRef]

10. Craft M, Croucher R, Dickinson J, James M, Clements M, Rodgers Al. Natural Nashers:a programme of dental health education for adolescents in schools. Int Dent J 1984;34:204-13.

11. Glasrud PH, Frazier PJ. Future elementary school teachers' knowledge and opinions about oral health and community programs. J Public Health Dent 1988;48:74-80. [CrossRef]

12. Loupe MJ, Frazier PJ. Knowledge and attitudes of schoolteachers toward oral health programs and preventive dentistry. J Am Dent Assoc 1983;107:229-34. [CrossRef]

13. Stephen $S$. Teachers as dental health educators. Odontostomatol Trop 1984;7:205-208.

14. Sgan-Cohen HD, Saadi S, Weissman A. Dental knowledge and attitudes among Arab schoolteachers in northern Israel. Int Dent J 1999;49:269-74. [CrossRef]

15. Abanto J, Carvalho TS, Mendes FM, Wanderley MT, Bonecker M, Raggio DP. Impact of oral diseases and disorders on oral healthrelated quality of life of preschool children. Community Dent Oral Epidemiol 2011;39:105-14. [CrossRef]

16. Jackson SL, Vann WF, Jr., Kotch JB, Pahel BT, Lee JY. Impact of poor oral health on children's school attendance and performance. Am J Public Health 2011;101:1900-6. [CrossRef]

17. Martins-Junior PA, Vieira-Andrade RG, Correa-Faria P, OliveiraFerreira F, Marques LS, Ramos-Jorge ML. Impact of early childhood caries on the oral health-related quality of life of preschool children and their parents. Caries Res 2013;47:2118. [CrossRef]

18. Peretz B, Ram D, Azo E, Efrat Y. Preschool caries as an indicator of future caries:a longitudinal study. Pediatr Dent 2003;25:114-8.

19. Christensen P. The health-promoting family:a conceptual framework for future research. Soc Sci Med 2004;59:377-87. [CrossRef]

20. Rossow I, Rise J. Concordance of parental and adolescent health behaviors. Soc Sci Med 1994;38:1299-305. [CrossRef]

21. Jain S, Bhat N, Asawa K, Tak M, Singh A, Shinde K, Gandhi N, Doshi A. Effect of Training School Teachers on Oral Hygiene Status of 8-10 Years Old Government School Children of Udaipur City, India. J Clin Diagn Res 2016;10:ZC95-99. [CrossRef]

22. Kay E, Locker D. A systematic review of the effectiveness of health promotion aimed at improving oral health. Community Dent Health 1998;15:132-44.

23. Mota A, Oswal KC, Sajnani DA, Sajnani AKOral Health Knowledge, Attitude, and Approaches of Pre-Primary and Primary School Teachers in Mumbai, India. Scientifica (Cairo) 2016;5967427. doi:10.1155/2016/5967427. [CrossRef]

24. Sekhar V, P S, M AE, L S, N B, K R. Knowledge, attitude and practice of school teachers towards oral health in Pondicherry. $J$ Clin Diagn Res 2014;8:ZC12- 5.

25. Ramroop V, Wright D, Naidu R. Dental health knowledge and attitudes of primary school teachers toward developing dental health education. West Indian Med J 2011; 60:576-80. 
26. Manjunath G, Kumar NN. Oral health knowledge, attitude and practices among school teachers in Kurnool-Andra Pradesh. J Oral Health Comm Dent 2013;7:17-23.

27. Ehizele A, Chiwuzie J, Ofili A. Oral health knowledge, attitude and practices among Nigerian primary school teachers. Int J Dent Hyg 2011;9:254-60. [CrossRef]

28. Petersen PE, Esheng Z. Dental caries and oral health behavior situation of children, mothers and schoolteachers in Wuhan, People's Republic of China. Int Dent J 1998;48:210-6. [CrossRef]

29. American Academy on Pediatric Dentistry. Policy on early childhood caries (ECC):classifications, consequences, and preventive strategies. Pediatr Dent 2008;30:40-3.

30. Prabhu A, Rao AP, Reddy V, Ahamed SS, Muhammad S, Thayumanavan S. Parental knowledge of pre-school child oral health. J Community Health 2013;38:880-4. [CrossRef]

31. Al-Zahrani AM, Al-Mushayt AS, Otaibi MF, Wyne AH. Knowledge and attitude of Saudi mothers towards their preschool children's oral health. Pak J Med Sci 2014;30:720-4.

32. Young C, Wong KY, Cheung LK Emergency management of dental trauma:knowledge of Hong Kong primary and secondary school teachers. Hong Kong Med J 2012;18:362-70.
33. Sae-Lim V Lim LP. Dental trauma management awareness of Singapore pre-school teachers. Dent Traumatol 2001;17:71-6. [CrossRef]

34. Andreasen JO. The effect of extra-alveolar period and storage media upon periodontal and pulpal healing after replantation of mature permanent incisors in monkeys. Int J Oral Surg 1981;10:43-53. [CrossRef]

35. Sae-Lim V, Yuen KW. An evaluation of after-office-hour dental trauma in Singapore. Endod Dent Traumatol 1997;13:164-70. [CrossRef]

36. Chan AW, Wong TK, Cheung GS. Lay knowledge of physical education teachers about the emergency management of dental trauma in Hong Kong. Dent Traumatol 2001;17:77-85. [CrossRef]

37. Mohandas U, Chandan GD. Knowledge, attitude and practice in emergency management of dental injury among physical education teachers:a survey in Bangalore urban schools. J Indian Soc Pedod Prev Dent 2009;27:242-8. [CrossRef]

38. Panzarini SR, Pedrini D, Brandini DA, Poi WR, Santos MF, Correa J. Physical education undergraduates and dental trauma knowledge. Dent Traumatol 2005;21:324-8. [CrossRef] 